\title{
THE INDIRECT HAEMAGGLUTINATION TEST IN DYSENTERY CAUSED BY SHIGELLA SONNEI AND SHIGELLA FLEXNERI
}

\author{
BY \\ J. HAVĹIK, B. KOTT, AND V. POTUŽN'IK \\ From the Intectious Diseases Clinic, Faculty of Hygiene, Prague, Bulovka, Czechoslovakia, and \\ the Regional Administration of Public Health, Centre of Hygiene and Epidemiology, Česklél \\ Budějovice, Czechoslovakia
}

(RECEIVED FOR PUBLICATION OCTOBER 10, 1958)

The examination of cultures of stools is mostly used in establishing the diagnosis of bacillary dysentery. Agglutination, the most frequently used serological investigation, does not give reliable results and is therefore not generally used.

The bacteriological examination of stools fails in a certain percentage of cases, irrespective of the mode of culture used. Particularly troublesome are examinations of stools in patients treated with antibiotics, for then the stools are usually negative. Patients with negative culture results are admitted to hospital and discharged with a vague diagnosis of gastro-enteritis or entero-colitis. This fact, however, can be very important epidemiologically, especially in children living in collective groups or persons employed in handling food.

Recent work, especially that of Neter and Walker (1954), Neter, Westphal, Lüderitz, and Gorzynski (1956a), and Neter, Gorzynski, Gino, Westphal, and Lüderitz (1956b), demonstrated the value of the haemagglutination technique in the diagnosis of enteric infections, so it was decided to use this method in the investigation of bacillary dysentery.

\section{Material}

The sera used in this study came from patients exhibiting symptoms ranging from typical acute dysentery to the asymptomless carrier. Sh. sonnei or Sh. flexneri was isolated from each individual. In some cases blood was first drawn 12 to 48 hours after the onset of symptoms, while in others two to four weeks had elapsed before the first sample of serum was obtained.

\section{Methods}

The techniques originally used were first introduced by Neter and Walker (1954) and Neter et al. (1956b), but now the following procedure (Potužník, Kott, and Havlík, 1958) is used.
Polyvalent Antigen Shigella sonnei.-Equal portions of agar-grown $\mathrm{S}$ and $\mathrm{R}$ phase $S h$. sonnei were suspended in physiological saline. The suspension was centrifuged and the sedimented cells resuspended in saline to a density equivalent to five times that of a 24-hour broth culture. This suspension was heated for about 90 minutes in the steamer and, after cooling, was centrifuged till an opalescent supernatant fluid was obtained which represented the crude antigen ready for use. This was divided into smaller vessels; it was sterilized by boiling in order to prolong its stability when stored at $+4^{\circ} \mathrm{C}$. The quality of the antigen was always verified by means of an agglutination test with immune rabbit serum against Shigella sonnei.

Polyvalent Antigen Shigella flexneri.-Equal parts of 24-hour agar cultures of Shigella flexneri types 1a, $1 b, 2 a, 2 b, 3,4 a, 4 b, 5$, and 6 were suspended in physiological saline solution. Final processing was the same as described for the production of the Shigella sonnei antigen.

Patients' Sera.-The sera were stored at $+4^{\circ} \mathrm{C}$. After the diagnosis had been proved bacteriologically the sera were tested with the appropriate antigens.

Erythrocytes.-Human. $\mathrm{O} \mathrm{Rh}$-negative erythrocytes washed three times and diluted to $10 \%$ were mixed with equal amounts of the polyvalent antigen Shigella sonnei or Shigella flexneri and kept for two hours in a water-bath of $37^{\circ} \mathrm{C}$. The modified erythrocytes were then washed three times in physiological saline to remove the excess antigen, which, even in minimal amounts, would produce an inhibitory effect. A $1 \%$ suspension of the modified erythrocytes was made which could be stored at $+4^{\circ} \mathrm{C}$. for as long as a week.

Test Procedure.-To $0.1 \mathrm{ml}$. amounts of doubling serial dilutions of inactivated serum was added $0.1 \mathrm{ml}$. of the $1 \%$ suspension of modified red cells. After mixing, all the test tubes were centrifuged for two minutes at 800 r.p.m. In a positive case a compact agglutination, which was dispersed only with difficulty, could be separated by gently tapping the test tube. 
In a negative case the erythrocytes dispersed easily. Each batch was checked with controls containing both normal and modified erythrocytes in physiological saline solution. Sera containing normal erythrocytes were also examined.

\section{Results}

Preliminary experiments were carried out to examine the reliability of the reaction. Thus red blood cells sensitized with either the polyvalent $S h$. sonnei antigen or the polyvalent Sh. flexneri antigen were tested in hyperimmune rabbit serun prepared against various members of the genus Enterobacteriaceae. The results are summarized in Tables I-IV and demonstrate that the test is highly specific.

TABLE I

TITRES OBTAINED WITH ERYTHROCYTES SENSITIZED WITH EITHER POLYVALENT SHIGELLA SONNEI OR SHIGELLA FLEXNERI EXTRACTS AND TESTED IN SAL MONELLA RABBIT ANTISERA

\begin{tabular}{|c|c|c|}
\hline \multirow{2}{*}{$\begin{array}{c}\text { Serum Prepared } \\
\text { against } \\
\text { Salmonella } \\
\text { Group* }\end{array}$} & \multicolumn{2}{|c|}{$\begin{array}{l}\text { Titre Obtained when Tested with } \\
\text { Erythrocytes Sensitized with Extract of }\end{array}$} \\
\hline & Sh. sonnei & Sh. flexneri \\
\hline $\begin{array}{l}9,12 \\
4,5,12 \\
6,7 \\
6,8 \\
3,10 \\
3,15 \\
\mathrm{Vi}\end{array}$ & $\begin{array}{c}1: 40 \pm \\
\text { Negative } \dagger \\
1: 20 \pm \\
\text { Negative } \\
, " \\
, " \\
, "\end{array}$ & $\begin{array}{c}1: 40 \\
1: 80 \\
1: 20 \\
\text { Negative } \\
\text { ", } \\
\text {," }\end{array}$ \\
\hline
\end{tabular}

* Serum obtained from Biogena. † Negative=less than 1: 20.

TABLE II

TITRES OBTAINED WITH ERYTHROCYTES SENSITIZED WITH EITHER POLYVALENT SHIGELLA SONNEI OR $S H I G E L L A$ FLEXNERI EXTRACTS AND TESTED IN E. COLI RABBIT ANTISERA

\begin{tabular}{|c|c|c|}
\hline \multirow{2}{*}{$\begin{array}{c}\text { Serum Prepared } \\
\text { against } \\
E . \text { coli } \\
\text { O Group }\end{array}$} & \multicolumn{2}{|c|}{$\begin{array}{l}\text { Titre Obtained when Tested with } \\
\text { Erythrocytes Sensitized with Extract of }\end{array}$} \\
\hline & Sh. sonnei & Sh. flexneri \\
\hline $\begin{array}{r}1 \\
2 \\
3 \\
4 \\
5 \\
6 \\
7 \\
8 \\
9 \\
10 \\
11 \\
12 \\
13 \\
14 \\
15 \\
16 \\
17 \\
18 \\
19 \\
20 \\
21 \\
22 \\
23 \\
24 \\
25\end{array}$ & 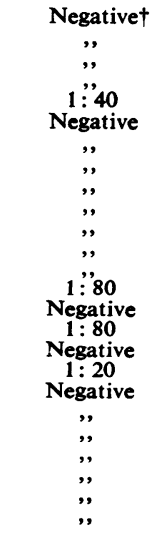 & 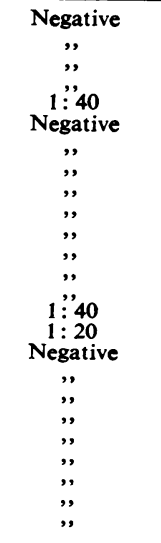 \\
\hline
\end{tabular}

* Serum obtained from Biogena. † Negative $=$ less than 1: 20.
TABLE III

TITRES OBTAINED WITH ERYTHROCYTES SENSITIZED WITH EITHER POLYVALENT SHIGELLA SONNEI OR SHIGELL A FLEXNERI EXTRACTS AND TESTED IN RABBIT PROTEUS VULGARIS ANTISERA*

\begin{tabular}{|c|c|c|}
\hline \multirow{2}{*}{$\begin{array}{l}\text { Serum Prepared } \\
\text { against } \\
\text { Proteus vulgaris } \\
\text { Group O+ }\end{array}$} & \multicolumn{2}{|c|}{$\begin{array}{l}\text { Titre Obtained when Tested with } \\
\text { Erythrocytes Sensitized with Extract of }\end{array}$} \\
\hline & Sh. sonnei & Sh. flexneri \\
\hline $\begin{array}{l}\text { I, II } \\
\text { I, III } \\
\text { I, IV } \\
\text { V } \\
\text { VII } \\
\text { VIII } \\
\text { IX } \\
\text { X } \\
\text { XII } \\
\text { XIII } \\
\text { XIV } \\
\text { XVII, XVII, XIX } \\
\text { XII, XIX, XX } \\
\text { XVII, XVIII } \\
\text { XXI } \\
\text { XXIII } \\
\text { XXIV } \\
\text { XXVIII } \\
\text { XXX } \\
\text { XXXII } \\
\text { XXXIII }\end{array}$ & $\begin{array}{c}\text { Negative: } \\
\text { ", } \\
\text { ", } \\
\text { ", } \\
\text { "' } \\
\text { 1:"20 } \\
\text { Negative } \\
\text { ", } \\
\text { ", } \\
\text { ", } \\
\text { ", }\end{array}$ & $\begin{array}{c}\text { Negative } \\
\text { ", } \\
\text {,' } \\
1: 80 \\
\text { Negative } \\
\text { ", } \\
\text { ": } \\
1: 20 \\
\text { Negative } \\
\text {," } \\
\text {," } \\
\text {," } \\
\text {," } \\
\text {," } \\
\text {," }\end{array}$ \\
\hline
\end{tabular}

* Division according to Kadlecová (Sedlák, 1955). † Serum obtained from Biogena. $\quad$ Negative=less than 1: 20.

TABLE IV

TITRES OBTAINED WITH ERYTHROCYTES SENSITIZED WITH EITHER POLYVALENT SHIGELLA SONNEI OR SHIGELLA FLEXNERI EXTRACTS AND TESTED IN RABBIT SHIGELLA ANTISERA

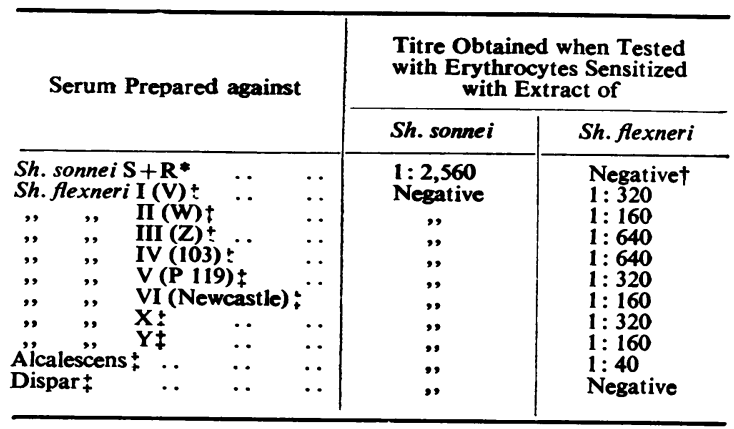

* Serum obtained from Biogena. † Negative=less than 1:20. ¥ Serum obtained from Wellcome.

Using a haemagglutination technique 50 samples of blood taken from umbilical veins of newborn infants were tested against $S h$. sonnei and Sh. flexneri antigens. All gave negative reactions.

Neither the time taken for centrifuging nor the speed of centrifugation influenced the result of the reaction.

The sera from 242 individuals from whom either Sh. sonnei or Sh. flexneri had been isolated were tested. Six hundred and twenty sera from 210 dysenteric patients suffering from Sonne infection were examined by the haemagglutination technique using polyvalent antigen $S h$. sonnei, 
TABLE V

TITRES OF AGGLUTINATING AND HAEMAGGLUTINATING ANTIBODIES IN SERA OF SUBJECTS SUFFERING FROM SONNE OR FLEXNER DYSENTERY

\begin{tabular}{|c|c|c|c|c|c|c|c|c|}
\hline \multirow{3}{*}{ No. } & \multicolumn{4}{|c|}{ Sera of Subjects with Sonne Dysentery } & \multicolumn{4}{|c|}{ Sera of Subjects with Flexner Dysentery } \\
\hline & \multicolumn{2}{|c|}{$\begin{array}{l}\text { Titres Obtained with } \\
\text { Sh. sonnei Antigen }\end{array}$} & \multicolumn{2}{|c|}{$\begin{array}{l}\text { Titres Obtained with } \\
\text { Sh. flexneri Antigen }\end{array}$} & \multicolumn{2}{|c|}{$\begin{array}{l}\text { Titres Obtained with } \\
\text { Sh. flexneri Antigen }\end{array}$} & \multicolumn{2}{|c|}{$\begin{array}{c}\text { Titres Obtained with } \\
\text { Sh. sonnei Antigen }\end{array}$} \\
\hline & $\begin{array}{c}\text { Agglu- } \\
\text { tination }\end{array}$ & $\begin{array}{c}\text { Haemag- } \\
\text { glutination }\end{array}$ & $\begin{array}{c}\text { Agglu- } \\
\text { tination }\end{array}$ & $\begin{array}{l}\text { Haemag- } \\
\text { glutination }\end{array}$ & $\begin{array}{c}\text { Agglu- } \\
\text { tination }\end{array}$ & $\begin{array}{c}\text { Haemag- } \\
\text { glutination }\end{array}$ & $\begin{array}{c}\text { Agglu- } \\
\text { tination }\end{array}$ & $\begin{array}{l}\text { Haemag- } \\
\text { glutination }\end{array}$ \\
\hline $\begin{array}{r}1 \\
2 \\
3 \\
4 \\
5 \\
6 \\
7 \\
8 \\
9 \\
10 \\
11 \\
12\end{array}$ & $\begin{array}{c}\text { Negative* } \\
\text { ", } \\
", \\
1: " 20 \\
1: 40 \\
1: 40 \\
1: 80 \\
1: 80 \\
1: 160 \\
1: 160\end{array}$ & $\begin{array}{ll}1: 50 \\
1: 100 \\
1: 100 \\
1: 150 \\
1: 200 \\
1: 600 \\
1: 400 \\
1: 600 \\
1: 300 \\
1: 600 \\
1: 300 \\
1: 1,200\end{array}$ & $\begin{array}{c}\text { Negative } \\
1: \text { 220 } \\
\text { Negative } \\
\text {," } \\
\text { ", } \\
\text { ", } \\
\text { ", }\end{array}$ & $\begin{array}{c}\text { Negative } \\
\text { ", } \\
1 \text { :"so } \\
\text { Negative } \\
\text { ", } \\
\text { ", } \\
\text { ", }\end{array}$ & $\begin{array}{c}\text { Negative } \\
\text { ", } \\
\text { ", } \\
\text { "’ } \\
1: 20 \\
1: 40 \\
1: 80 \\
1: 80 \\
1: 80 \\
1: 320\end{array}$ & $\begin{array}{ll}1: 50 \\
1: 50 \\
1: 100 \\
1: 150 \\
1: 200 \\
1: 300 \\
1: 300 \\
1: 300 \\
1: 200 \\
1: 400 \\
1: 600 \\
1: 2,400\end{array}$ & $\begin{array}{c}\text { Negative } \\
", \\
, " \\
1: " 20 \\
1: 20 \\
1: 20 \\
1: 20 \\
\text { Negative } \\
1: 20 \\
\text { Negative }\end{array}$ & $\begin{array}{c}\text { Negative } \\
1: 50 \\
1: 50 \\
1: 50 \\
\text { Negative } \\
1: 100 \\
1: 100 \\
1: 100 \\
1: 50 \\
\text { Negative } \\
1: 50 \\
1: 150\end{array}$ \\
\hline
\end{tabular}

* Negative=by agglutination less than 1:20; by haemagglutination less than 1:50.

and 69 sera from 32 dysenteric patients with Flexner infection were examined by the same technique using polyvalent antigen Sh. flexneri. Finally 12 sera from individuals suffering from Sonne shigellosis and 12 sera from individuals suffering from Flexner shigellosis were examined using haemagglutination and the Widal technique with both polyvalent antigens in both groups of sera (Table V). The agglutinin titres, using the Widal technique, were either negative or low, and always lower than the titres obtained by the haemagglutination test. Some sera gave positive titres against both shigellas; we believe that these reactions are specific and are due to previous dysentery infection with the other type of Shigella.

In the group of 12 patients all suffering from Flexner dysentery (Table V) positive haemagglutinin titres against $S h$. sonnei were often found. In repeated tests Sh. flexneri haemagglutinins were markedly unstable, whereas the Sh. sonnei haemagglutinins did not change. These patients were all children from a group living in an institution where Sonne dysentery had been found some time before. During the period in hospital an average of three samples of serum at five-day intervals was taken from these patients.

The titre $1: 50$ is thought suggestive of infection, whereas the titre $1: 100$ and higher is accepted as positive. Obviously only repeated examinations are of diagnostic value, the rise in antibody being very significant. Suggestive titres usually appeared about six to eight days after the onset of symptoms and remained positive for several weeks at least. It may be stressed that even in mild attacks of the disease and in so-called asymptomatic carriers positive antibody levels could be demonstrated in the majority of cases.

As can be seen in Table VI most sera showed a positive or at least a suggestive result in the first specimen; in the later specimens the titres were

TABLE VI

TITRES OF HAEMAGGLUTINATING ANTIBODIES IN SERA OF SUBJECTS SUFFERING FROM SONNE OR FLEXNER DYSENTERY

\begin{tabular}{|c|c|c|c|c|c|c|c|c|c|c|}
\hline \multirow{3}{*}{ Titre } & \multicolumn{5}{|c|}{ Sera of Subjects with Sonne Dysentery } & \multicolumn{5}{|c|}{ Sera of Subjects with Flexnor Dysentery } \\
\hline & \multicolumn{4}{|c|}{$\begin{array}{l}\text { Intervals of Blood Samples from } \\
\text { Beginning of Illness }\end{array}$} & \multirow{2}{*}{$\begin{array}{l}\text { No. of } \\
\text { Examined } \\
\text { Sera }\end{array}$} & \multicolumn{4}{|c|}{$\begin{array}{c}\text { Intervals of Blood Samples from } \\
\text { Beginning of Illness }\end{array}$} & \multirow{2}{*}{$\begin{array}{l}\text { No. of } \\
\text { Sera } \\
\text { Examined }\end{array}$} \\
\hline & $\begin{array}{l}1-7 \\
\text { Days }\end{array}$ & $\begin{array}{l}\text { 8-14 } \\
\text { Days }\end{array}$ & $\begin{array}{l}15-42 \\
\text { Days }\end{array}$ & More & & $\begin{array}{c}1-7 \\
\text { Days }\end{array}$ & $\begin{array}{l}8-14 \\
\text { Days }\end{array}$ & $\begin{array}{l}15-42 \\
\text { Days }\end{array}$ & More & \\
\hline $\begin{array}{c}\text { Negative* } \\
1: 50 \\
1: 100 \\
1: 200 \\
1: 300 \\
1: 400 \\
1: 600 \\
1: 800 \\
\text { Higher }\end{array}$ & $\begin{array}{r}26 \\
15 \\
9 \\
4 \\
5 \\
7 \\
6 \\
1 \\
0\end{array}$ & $\begin{array}{r}5 \\
29 \\
46 \\
31 \\
28 \\
16 \\
19 \\
7 \\
7\end{array}$ & $\begin{array}{r}10 \\
36 \\
81 \\
95 \\
35 \\
28 \\
10 \\
4 \\
3\end{array}$ & $\begin{array}{r}12 \\
11 \\
13 \\
13 \\
2 \\
3 \\
2 \\
0 \\
1\end{array}$ & $\begin{array}{r}53 \\
91 \\
149 \\
143 \\
70 \\
54 \\
37 \\
12 \\
11\end{array}$ & $\begin{array}{l}6 \\
4 \\
3 \\
1 \\
1 \\
0 \\
1 \\
0 \\
1\end{array}$ & $\begin{array}{l}1 \\
3 \\
5 \\
3 \\
2 \\
2 \\
1 \\
1 \\
2\end{array}$ & $\begin{array}{l}0 \\
2 \\
5 \\
6 \\
5 \\
4 \\
2 \\
0 \\
2\end{array}$ & $\begin{array}{l}0 \\
0 \\
2 \\
2 \\
1 \\
0 \\
1 \\
0 \\
0\end{array}$ & $\begin{array}{r}7 \\
99 \\
15 \\
12 \\
6 \\
5 \\
1 \\
5\end{array}$ \\
\hline Total & 73 & 188 & 302 & 57 & 620 & 17 & 20 & 26 & 6 & 69 \\
\hline
\end{tabular}

* Negative= less than 1: 50. 
positive. Of the sera with high titres, 1:600 and higher, no direct relationship was shown to exist between the high titres and either the severity of the illness or the treatment. The titres obtained are shown in Table VI.

\section{Discussion}

In the past bacillary dysentery has not been diagnosed by the demonstration of agglutination in patients' sera, first because positive results are obtained in diseases other than bacillary dysentery, and secondly because a large number of patients fail to develop detectable agglutinins. Cruickshank and Swyer (1940) showed that a rise in titre occurred in patients with Sonne dysentery, and Seeliger (1953) suggests a certain diagnostic significance to agglutination tests in patients whose disease is caused by Sh. shigae, Sh. schmitzi, Sh. boydii, and Sh. sonnei, non-specific reactions being exceptional in these infections.

On the other hand, Seeliger considers the evaluation of positive titres against Sh. flexneri as difficult, since this group is closely related antigenically to a number of Gram-negative rods.

The haemagglutination test in dysentery was first used by Neter and Walker (1954), who showed that specific titres were obtained even in the acute phase of the disease and that the titre remained high for a considerable length of time (Neter and Dunphy, 1957).

Another advantage of the haemagglutination test is that erythrocytes are able to adsorb fully on their surface several antigens simultaneously (Hayes, 1951 ; Neter, Bertram, and Arbesman, 1952 ; Landy, 1954).

Neter, Westphal, Lüderitz, and Gorzynski (1956a), Neter et al. (1956b), and Neter and Dunphy (1957) used polyvalent sensitized erythrocytes for the diagnosis of various diseases due to Enterobacteriaceae, to which the dysenteries also belong.

The results presented in this study show that the haemagglutination procedure is highly specific and more sensitive than agglutination and should therefore be used in the diagnosis of bacillary dysentery.
It is not suggested that this serological technique should be used to the exclusion of cultural techniques; nevertheless haemagglutination can be an important diagnostic tool, especially in patients in whom therapy has started and stool cultures are negative.

\section{Summary}

From control tests and the results of examining 689 sera from patients suffering from Sonne or Flexner dysentery proved by culture, the following conclusions may be drawn :

(1) The haemagglutination test demonstrates raised specific titres in the sera of dysenteric patients where Sh. sonnei or Sh. flexneri was the infecting agent.

(2) A titre of 1:50 is regarded as suspicious, $1: 100$ and higher as positive.

(3) Repeated examinations of patients' sera show a rise in Shigella agglutinins during the course of the disease.

(4) Haemagglutination antibodies are present in the sera of patients with atypical disease and in symptomless carriers.

(5) The haemagglutination technique is particularly valuable as a means of proof of the disease in patients undergoing treatment with antibiotics and whose faeces yield negative cultures.

(6) The haemagglutination test does not replace the need for isolation of the causal organism.

\section{REFERENCES}

Cruickshank, R., and Swyer, R. (1940). Lancet, 2, 803.

Hayes, L. (1951). Aust. J. exp. Biol. med. Sci., 29, 51.

Landy, M. (1954). Amer. J. publ. Hlth, 44, 1059.

Neter, E., and Dunphy, D. (1957). Pediatrics, 20, 78.

- and Walker, J. (1954). Amer. J. clin. Path., 24, 1424.

Bertram, L. F., and Arbesman, C. E. (1952). Proc. Soc. exp. Biol. (N.Y.), 79, 255.

J.exp. Med., A6, 1 .

- Westphal, O., Lïderitz, O., and Gorzynski, E. A. (1956a). Ann. N.Y. Acad. Sci., 66, 141.

Gorzynski, E. A., Gino, R. M., Westphal, O., and Lüderitz, O. (1956b). Canad. J. Microbiol., 2, 232.

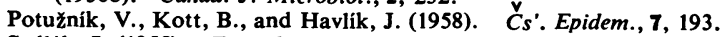
Sedlák, J. (1955). Enterobacteriaceae, p. 142. Stát. zdrav. naklad., Prague.

Seeliger, H. (1953). Die Laboratoriumsdiagnostik der Bakterienruhr, p. 43. J. A. Barth, Leipzig. 